\title{
Late adult-onset Hereditary Sensory and Motor Neuropathy due to TECPR2 mutations
}

\author{
Neuropatia hereditária sensitivo-motora de início tardio no \\ adulto devido a mutações no gene TECPR2
}

\section{Neuropatía hereditária sensitivomotora de início tardío en el adulto por mutaciones en TECPR2}

Paulo Victor Sgobbi de Souza1, Bruno de Mattos Lombardi Badia², Eduardo Augusto Gonçalves ${ }^{3}$, Roberta Ismael Lacerda Machado4, José Marcos Vieira de Albuquerque Filho ${ }^{5}$, Igor Braga Farias ${ }^{6}$, Alexandre Bussinger Lopes ${ }^{7}$, Wladimir Bocca Vieira de Rezende Pinto ${ }^{8}$, Acary Souza Bulle Oliveira9

\begin{abstract}
1.MD, Division of Neuromuscular Diseases, Department of Neurology and Neurosurgery, Universidade Federal de São Paulo (UNIFESP), São Paulo-SP, Brazil. ORCID: 0000-0002-7416-7108.

2.MD, Division of Neuromuscular Diseases, Department of Neurology and Neurosurgery, Universidade Federal de São Paulo (UNIFESP), São Paulo-SP, Brazil. ORCID: 0000-0001-7360-0494.

3.MD, Division of Neuromuscular Diseases, Department of Neurology and Neurosurgery, Universidade Federal de São Paulo (UNIFESP), São Paulo-SP, Brazil. ORCID: 0000-0002-9893-2468.

4.MD, Division of Neuromuscular Diseases, Department of Neurology and Neurosurgery, Universidade Federal de São Paulo (UNIFESP), São Paulo-SP, Brazil. ORCID: 0000-0002-5842-0062.

5.MD, Division of Neuromuscular Diseases, Department of Neurology and Neurosurgery, Universidade Federal de São Paulo (UNIFESP), São Paulo-SP, Brazil. ORCID: 0000-0002-4533-2637.

6.MD, Division of Neuromuscular Diseases, Department of Neurology and Neurosurgery, Universidade Federal de São Paulo (UNIFESP), São Paulo-SP, Brazil. ORCID: 0000-0003-2187-6573.

7.MD, Division of Neuromuscular Diseases, Department of Neurology and Neurosurgery, Universidade Federal de São Paulo (UNIFESP), São Paulo-SP, Brazil.

8.MD, MSc, Division of Neuromuscular Diseases, Department of Neurology and Neurosurgery, Universidade Federal de São Paulo (UNIFESP), São Paulo-SP, Brazil. ORCID: 0000-0002-0150-525X.

9.MD, PhD, Division of Neuromuscular Diseases, Department of Neurology and Neurosurgery, Universidade Federal de São Paulo (UNIFESP), São Paulo-SP, Brazil. ORCID: 0000-0002-6986-4937.
\end{abstract}

\begin{abstract}
Resumo
Objetivo. Descrição de nova associação genética da doença de Charcot-Marie-Tooth (CMT) axonal de início tardio. Método. Paciente brasileira do sexo feminino de 57 anos apresentouse com histórico de parestesias, e amiotrofia com paraparesia crural nos membros inferiores desde os 50 anos. Exame neurológico revelou amiotrofia peroneal, pes cavus bilateral, fraqueza muscular distal leve, hipopalestesia e hipoestesia dolorosa e térmica nos membros inferiores, além de hiperreflexia global. Resultados. Estudos neurofisiológicos evidenciaram a presença de polineuropatia axonal sensitivo-motora crônica. Sequenciamento completo do genoma revelou a presença de variantes patogênicas no gene TECPR2 (14q32.31). Conclusão. Esta nova apresentação genética de CMT axonal de início tardio com hiperreflexia associada ao gene TECPR2.
\end{abstract}

Unitermos. doença de Charcot-Marie-Tooth; Paraplegia Espástica Hereditária; Neuropatia Hereditária Sensitivo-Motora; SPG49; TECPR2

\footnotetext{
Abstract

Objective. The description of a new genetic association with late-onset axonal Charcot-MarieTooth disease (CMT). Method. A 57-year-old Brazilian woman presented with a slowly progressive history of paresthesia, muscle wasting and weakness in her lower limbs since age 50 years. Examination disclosed peroneal amyotrophy, bilateral pes cavus, mild distal weakness, reduced vibration, pain and temperature sensation in the lower limbs and brisk
} 
tendon reflexes. Results. Neurophysiological studies showed chronic sensorimotor axonal polyneuropathy. Whole-genome sequencing showed compound heterozygous pathogenic variants in the TECPR2 gene (14q32.31). Conclusion. This novel genetic presentation of lateonset axonal CMT with brisk tendon reflexes associated with TECPR2.

Keywords. Charcot-Marie-Tooth disease; Hereditary Spastic Paraplegia; Hereditary Sensory and Motor Neuropathy; SPG49; TECPR2

\section{Resumen}

Objetivo. Descripción de una nueva asociación genética de la moléstia de Charcot-MarieTooth (CMT) axonal de início tardío. Método. Una paciente brasileña de 57 años presentó con histórico de parestesías, dorméncia y amiotrofia con paraparesia crural en las piernas desde los 50 años de edad. El exámen neurológico mostró amiotrofía peroneal, pes cavus bilateral, debilidad muscular distal leve, hipopalestesía y hipoestesia dolorosa y térmica distal en las piernas asociada a aumento de los reflexos tendíneos. Resultados. Estudios neurofisiológicos evidenciaran la presencia de polineuropatía axonal sensitivomotora crónica. Secuenciamento completo del genoma evidenció la presencia de los variantes patogénicas en el gene TECPR2 (14q32.31). Conclusión. Esta nueva presentación genética de CMT axonal de início tardío con reflejos hiperactivos associada al gene TECPR2.

Palabras clave. moléstia de Charcot-Marie-Tooth; Paraparesía Espástica Hereditária; Neuropatía Hereditária Sensitivo-Motora; SPG49; TECPR2

Research developed at .Universidade Federal de São Paulo (UNIFESP), São Paulo-SP, Brazil.

Corresponding address: Wladimir Bocca VR Pinto. Department of Neurology and Neurosurgery, Universidade Federal de São Paulo (UNIFESP), São Paulo-SP, Brazil. R. Embau 67. CEP 04039-060. Vila Clementino, São Paulo-SP, Brazil. Phone +55(11)5083-1051. Fax +55(11)5571-3324. E-mail wladimirbvrpinto@gmail.com

\section{INTRODUCTION}

Axonal CMT represents a complex expanding group of neurodevelopmental and neurodegenerative disorders which has been related to more than 40 distinct genetic loci and 20 different pathophysiological mechanisms ${ }^{1}$, including intraneuronal disturbances of autophagy (i.e. CMT2B, CMT20) showing a common monogenic basis with some subtypes of Hereditary Spastic Paraplegia (HSP) and other neurodegenerative disorders ${ }^{2}$. Despite the presence of a common clinical and neurophysiological basis for most genetic subtypes, neurological and systemic involvement is 
heterogeneous among subtypes and there is marked overlapping with HSP and distal hereditary motor neuronopathies ${ }^{1,3}$.

\section{METHOD}

\section{Case report}

A 57-year-old Brazilian woman presented with a slowly progressive clinical history of numbness, paresthesia, muscle wasting and weakness in her lower limbs since age 50 years. Parental consanguinity was absent. No familial history of neuromuscular complaints was identified. Evaluation disclosed moderate peroneal amyotrophy, bilateral pes cavus (Figure 1), mild distal weakness for plantar flexion and extension, reduced vibration, pain, and temperature sensation in the distal portion of the lower limbs and global brisk tendon reflexes.

Full consent was obtained from the patient for this manuscript. This study was approved by our Institutional Ethics Committee (CEP-UNIFESP/HSP no 0985/2019).

\section{RESULTS}

Lab exams showed normal general serological testing, normal serum levels of copper, cobalamin and homocysteine, and a normal complete rheumatologic profile. Neurophysiological studies showed chronic sensorimotor axonal polyneuropathy. Neuroconduction disclosed no motor 
conduction blocks and no reduction of sensory and motor nerve conduction velocities but marked reduction of Sensory Nerve Action Potential amplitude on medial, ulnar, radial and sural nerves and moderate reduction of Compound Motor Action Potential amplitude on median, ulnar, common peroneal and tibial nerves. Cerebrospinal fluid analysis was unremarkable. Brain and spine MR imaging showed mild to moderate cortical atrophy and normal corpus callosum (Figure 1). As an atypical late-onset presentation of axonal Charcot-Marie-Tooth disease (CMT) was suspected, wholegenome sequencing was performed and showed compound heterozygous pathogenic variants c.3076-62G>A (p. $(=))$ and c. $3316+112 \mathrm{~T}>\mathrm{C}(\mathrm{p} .(=))$ in two intronic regions of the TECPR2 gene (14q32.31), both predicted as probably pathogenic according to $1000 \mathrm{G}$ (1000 genomes) and present in the dbSNP (Single Nucleotide Polymorphism) database (rs76998408 and rs2281702) and in the BIPMed (Brazilian Initiative on Precision Medicine).

\section{DISCUSSION}

The TECPR2 (tectonin beta-propeller repeat-containing protein 2) protein is involved in intraneuronal autophagy pathways by targeting proteins to the lysosome and autophagosome nucleation as a positive regulator ${ }^{2}$. Disturbances of autophagy have been associated as a pathophysiological mechanism in axonal subtypes of $\mathrm{CMT}^{1,2}$, most with earlier presentations than observed in this case. 
Figure 1. Examination findings and neuroimaging studies in the proband with TECPR2 gene mutations. (A) Examination showing pes cavus and finger retraction. Brain MR imaging showing normal cerebellum and corpus callosum in sagittal T1-sequence (B) and only mild cortical atrophy in FLAIR (C) and T2-weighted sequences (D).

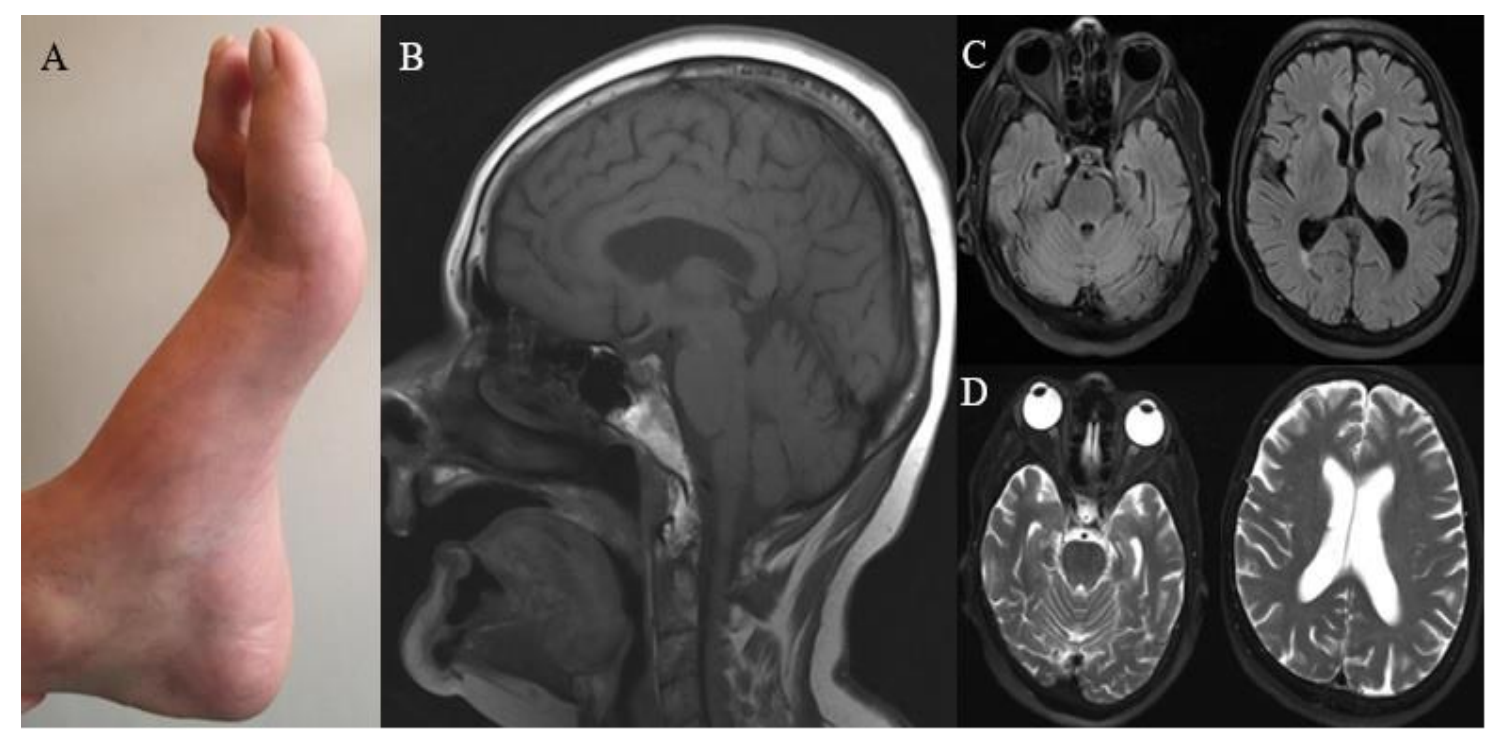

Source: corresponding author's own archive. Reproduced with the patient's permission and informed consent.

TECPR2 gene mutations have been previously associated with SPG49 (MIM \#615031) in Jewish Bukharian patients and a subtype of Hereditary Sensory and Autonomic Neuropathy (HSAN) ${ }^{4,5}$. SPG49 is an autosomal recessive complex HSP evolving during infancy with progressive spasticity, delayed psychomotor development, cerebellar ataxia, dysmorphisms, seizures and central apneic episodes $^{4}$. The HSAN subtype is marked by intellectual disability, severe paroxysmal dysautonomic events and progressive spasticity ${ }^{5}$. 


\section{CONCLUSÃO}

This novel genetic presentation of late-onset axonal CMT with brisk tendon reflexes demonstrates the complex genetic basis of TECPR2-associated neurodegeneration, expanding the phenotypic spectrum previously restricted to SPG49 and HSAN.

\section{REREFÊNCIAS}

1.Shy ME, Patzko A. Axonal Charcot-Marie-Tooth disease. Curr Opin Neurol 2011;24:475-83. http://dx.doi.org/10.1097/wco.0b013e32834aa331

2.Menzies FM, Fleming $A$, Caricasole A, Bento CF, Andrews SP, Ashkenazi $A$, et al. Autophagy and neurodegeneration: pathogenic mechanisms and therapeutic opportunities. Neuron 2017;93:1015-34. http://dx.doi.org/10.1016/j.neuron.2017.01.022

3.De Souza PVS, de Rezende Pinto WBV, de Rezende Batistella GN, Bortholin T, Oliveira ASB. Hereditary Spastic Paraplegia: Clinical and Genetic Hallmarks. Cerebellum 2017; 16:525-51.

http://dx.doi.org/10.1007/s12311-016-0803-z

4.Oz-Levi D, Ben-Zeev B, Ruzzo EK, Hitomi Y, Gelman A, Pelak K, et al. Mutation in TECPR2 reveals a role for autophagy in hereditary spastic paraparesis. Am J Hum Genet 2012;91:1065-72.

http://dx.doi.org/10.1016/j.ajhg.2012.09.015

5.Helmer G, Oz-Levi D, Eyal E, Edvardson S, Nissenkorn A, Ruzzo EK, et al. TECPR2 mutations cause a new subtype of familial dysautonomia like hereditary sensory autonomic neuropathy with intellectual disability. Eur J Paediatr Neurol 2016;20:69-79.

http://dx.doi.org/10.1016/j.ejpn.2015.10.003 